\title{
ARAMEJSKA WERSJA KSIĘGI SOFONIASZA
}

Księga Sofoniasza należy do zbioru Dwunastu Proroków, o których autor Księgi Syracha napisał: „A potem było dwunastu proroków. Niech ich kości ze swego miejsca powrócą do życia! Pocieszyli oni Jakuba uratowali go wiarygodną nadzieją" $(49,10)$. Tekst wskazuje, że zbiór tych dwunastu ksiąg prorockich przekazywał słowa pocieszenia i nadziei. Jednak słowa te były głoszone w wielu miejscach w czasach zagrożenia, zapowiedzi o nadchodzącej katastrofie, także rozpaczy. Natomiast przekaz Księgi Syracha ukazuje przekonania czasów, w których żył jej autor. Stanowi to centralny aspekt rozwoju tradycji. Księgi prorockie były bowiem przekazywane nie tyle z powodu „wypełnienia” lub „niewypełnienia” proroctw, jakie zawierają, lecz w związku z nadzieją, którą tchnęły w serca słuchaczy. Wszystkie te księgi kończą się bowiem wzmianką o wybawieniu lub nadziei, która stanowi klucz interpretacyjny dla przyszłych grup czytelników. ${ }^{1}$

Wprawdzie w tradycji chrześcijańskiej i żydowskiej Księga Sofoniasza nie była tak często cytowana i nie odgrywała tak znaczącej roli jak pozostałe księgi prorockie, to jednak zawsze uznawano ją za tekst święty i w tym duchu odczytywały ją i interpretowały kolejne

1 E. Zw i, A Historical-Critical Study of the Book of Zephaniah, Berlin-New York 1991, s. 21-22, podkreśla, że interpretacja zorientowana na przyszłość często prowadziła do rozumienia danej księgi prorockiej jako skomplikowanego systemu kryptogramów, odnoszącego się do sytuacji życiowej wspólnoty, w której dokonywano interpretacji. Przyszłość, o której mówi prorok, mogła stać się lub stopniowo stawała się teraźniejszością (np. qumrańskie peszery). Mogła też przybrać formę przyszłości apokaliptycznej (np. Apokalipsa Sofoniasza), można ją było też interpretować eschatologicznie lub mogła stać się dowolną kombinacją tych trzech interpretacji. 
pokolenia. ${ }^{2} \mathrm{~W}$ artykule tym zostaną wskazane ważniejsze zmiany, obecne w przekładzie aramejskim Księgi Sofoniasza, które wprowadzono ze względów teologicznych. ${ }^{3}$ Warto zaznaczyć, że w targumie zachodzą również innego rodzaju zmiany, które zostaną wspomniane na końcu artykułu, szczególnie modyfikacje lingwistyczne i charakterystyczne zmiany nazw geograficznych.

\section{Przekład Księgi Sofoniasza w Targumie Jonatana}

Targum Sofoniasza, podobnie jak inne aramejskie przekłady Proroków Mniejszych, wchodzi w skład oficjalnie uznanego przez wspólnoty żydowskie Targumu Jonatana do Proroków. ${ }^{4}$ Datowanie

2 Na temat interpretacji w przekładach aramejskich zob. m.in. W. S m e li k, Translation and Commentary in One: The Interplay of Pluses and Substitutions in the Targum of the Prophets, JSJ 29/1998, s. 245-260; t e n ż e, The Rabbinic Reception of Early Bible Translations as Holy Writings and Oral Torah, JAB 1/1999, s. $249-272$.

3 Tłumaczenie i opracowanie Targumu Jonatana, które ukazało się w języku angielskim, obejmuje pięć tomów Aramaic Bible. The Targums (t. 10-14). Tom 14 to Targum Dwunastu Proroków Mniejszych, a w nim Targum Sofoniasza opracowany przez K. J. Carthcarta i R. P. Gordona. Zob. K. J. C a t h c a r t, R. P. G or d o n, The Targum of the Minor Prophets, AB 14, Edinburgh 1989. Przytoczone tu cytaty z Targumu Sofoniasza to tłumaczenia własne na podstawie aramejskiego tekstu wydanego w: M. C o h e n (oprac.), Mikraot Gedolot HaKeter, Bar Ilan University Press, 1992-, udostępnionego w elektronicznej wersji: Comprehensive Aramaic Lexicon, Targum Jonathan to the Prophets, Hebrew Union College, 2005. Korzystano także z tekstu aramejskiego opracowanego przez J. R i b e r a F l o r it, $L a$ version aramaica del Profeta Sofonias, Estudios Bíblicos 40/1982, s. 127-158 oraz tekstu, przekładu i komentarza A. H o, The Targum of Zephaniah. Manuscript and Commentary, SAIS t. 7, Leiden-Boston 2009.

4 Na temat nazwy Targumu Jonatana, datacji i pochodzenia, zob. m.in. K. J. Cath c a r t, R. P. Gordon, The Targum of the Minor Prophets, 1; P. V. M. Fle sh e r, B. Chilto n, The Targums. A Critical Introduction, Waco 2011, s. 171; zob. też A. K u ś m i r e k, Księga Nahuma w tradycji targumicznej, Collectanea Theologica 81 (2011) nr 4, s. 101-103; t a ż, Aramejska wersja Ksiegi Amosa w Targumie Jonatana, Collectanea Theologica 85(2015) nr 4, s. 177-178. 
Targumu Jonatana i czas powstania znajdujących się w nim tradycji stanowią punkt sporny współczesnych komentatorów. ${ }^{5}$

Choć Targum Jonatana ma czasem charakter parafrazujący, przekład ten odpowiada każdemu słowu z tekstu masoreckiego. Aramejski tłumacz posługiwał się tekstem hebrajskim nie tylko po to, by wiernie przekazać słowo Boże, ale przede wszystkim by wyrazić pewne idee teologiczne i nauki wypracowane w trudnym okresie, mianowicie po zniszczeniu Drugiej Świątyni. W tej sytuacji Żydzi chcieli zachować, a nawet jeszcze zacieśnić, łączność ze słowem. Targum Jonatana funkcjonował jako zawierający nauki instrument podtrzymujący nadzieję. Stał się przekazem takich emocji narodowych jak gniew, rozczarowanie, frustracja i nadzieja. Przekaz Targumu Sofoniasza podkreśla, że prorocy nie tylko zapowiadali przyszłość, ale też proklamowali wyzwolenie.

Można powiedzieć, że przekonania i oceny Targumu Sofoniasza dochodzą do głosu w każdej scenie i wierszu, od pierwszego do ostatniego. Choć targum zaczyna się mocnym uderzeniem, takim jak zniszczenie, i od obrazów strasznej śmierci, to jednak stopniowo łagodzi przekaz, a pod koniec ukazuje duchową bliskość między Bogiem a powracającymi z niewoli - raczej tylko tymi, a nie całym zgromadzeniem $(3,19)$. W ślad za biblijną Księgą Sofoniasza Targum Proroków Mniejszych przechodzi w nastroju od intensywnego gniewu i bólu do równie gorącej miłości i współczucia.

Charakterystyczna homiletyka interpretacyjna Targumu Jonatana jest jednak w Targumie Sofoniasza dość ograniczona. Targumiście nie wolno było zmienić świętego tekstu, ale mógł postarać się go zmodyfikować i dopasować do swoich czasów. ${ }^{6}$ Dzieło istniejące dzisiaj to mieszanka dwóch metod, które wykształciły się w okresie wczesnego nauczania Ezdrasza: przekładu dosłownego jako funda-

5 K. J. C a t h c a r t, R. P. G o r d o n, The Targum of the Minor Prophets, s. 18.

6 L. S m o l a r, M. A b e r b a c h, Studies in Targum Jonathan to the Prophets, New York 1983, s. 1-227 oraz druga część publikacji, czyli reprint książki: P. C h u rg i n, Targum Jonathan to the Prophets, New Haven 1927, s. 9-152 (w publikacji s. 229-380). 
mentalnego zadania translatora oraz funkcji interpretacyjnej, polegającej na nadaniu tekstowi sensu, by miał konkretne znaczenie dla pokolenia obecnego i następnych, by dawał lekcje życia zarówno dla człowieka indywidualnie, jak i dla wspólnoty.

\section{Prorok Sofoniasz we wczesnej tradycji żydowskiej}

Większość tradycji żydowskich o Sofoniaszu zajmowała się zagadnieniami historycznymi lub biograficznymi, tzn. miały one na celu objaśnienie takich czy innych aspektów życia proroka, jego przepowiadania i miejsca w przekazywaniu Bożego pouczenia.

W tekście hebrajskim prorok Sofoniasz pojawia się jako Żyd, który naucza w Jerozolimie w czasach, które poprzedzają reformę króla Judy, Jozjasza (622 r. przed Chr.) i upadek Niniwy (612 r. przed Chr.). W tradycji rabinicznej Sofoniasz został uznany za wnuka wielkiego króla Ezechiasza (715-687 przed Chr.) i nauczyciela proroka Jeremiasza. Według tej samej tradycji Sofoniasz otrzymał Torę od Habakuka i jego otoczenia. Za tekstem hebrajskim w traktacie Megilla Talmudu babilońskiego jest mowa, że Sofoniasz mieszkał w Jerozolimie (b.Meg. 15a) i był synem proroka (Kusziego, syna Gedaliasza). ${ }^{7}$

W midraszu Pesikta Rabbati ${ }^{8}$ wymienia się go również obok Jeremiasza i Huldy, jako tego, który głosił słowo Boże temu samemu pokoleniu tyle, że w innych realiach społecznych: Hulda kierowała swe orędzie do kobiet, Jeremiasz występował na ulicach, a Sofoniasz zabierał głos w synagogach $(26,129 b) .{ }^{9}$ Według tej samej tradycji, Sofoniasz, razem z Izajaszem, Jeremiaszem i Ezechielem, był prorokiem wysłanym przez Boga, aby przepowiedzieć karę, którą Pan nałożył

7 Na temat interpretacji Sofoniasza w tradycji rabinicznej, zob. E. Zw i, A Historical-Critical Study of the Book of Zephaniah, s. 23-24; zob. też: J. R ib e r a F lo r i t, La versión aramaica del Profeta Sofonías, s. 127-128.

8 Midrasz ten powstał prawdopodobnie w IX w. O tej tradycji wspomina Radak w swym komentarzu do Sofoniasza, podobne świadectwo występuje u Abrabanela, zob. E. Zw i, A Historical-Critical Study of the Book of Zephaniah, s. 23.

9 Tamże; zob. też: J. R i b e r a F lo r i t, La versión aramaica del Profeta Sofonías, s. 127. 
na Amonitów i Moabitów, potomków Lota. Tak samo mówi się, że Mesjasz, kiedy rozpocznie swoją misję, otoczy się czternastoma doradcami, jedni będą nosić tytuł pasterzy, a inni książąt. Sofoniasz znajdzie się, razem z Eliaszem i Amosem, między książętami. Grób tego proroka miał się znajdować niedaleko od Sydonu (Fenicja). ${ }^{10}$

Według jeszcze innej tradycji Księga Dwunastu Proroków została napisana przez mężów należących do Wielkiego Zgromadzenia (b. B. Bat. 15a), czyli w okresie perskim. Już w czasach starożytnych zastanawiano się, czy owo „zgromadzenie” sygnalizuje, że księgi te „spisano” czy „interpretowano”. Według Rasziego chodziło o spisanie. Stanowisko wyrażone w Abot R. Nat. 1,2-3 mówi jednak o interpretacji. Wypowiedź R. Chanany, znajdująca się w Pesiqta Rab. Kahana, rozdział Nahamu 10, można rozumieć w ten sposób, jakoby Sofoniasz działał (również?) po zburzeniu świątyni. ${ }^{11}$

W dziele pt. Vita prophetarum znajduje się informacja, że Sofoniasz: „Pochodził z plemienia Symeona, z okolic Sabaratha, i przepowiedział na temat miasta i na temat końca narodów i pomieszania nikczemnych. Kiedy zmarł, został pochowany we własnej okolicy". ${ }^{12}$

Pod koniec I w. została napisana prawdopodobnie również Apokalipsa Sofoniasza, ${ }^{13}$ co potwierdzałoby, że tradycja żydowska, zarówno ortodoksyjna, jak i sekciarska, łączy tego proroka bezpośrednio z erą eschatologiczną. Również w świecie esseńskim z Qumran istnieje komentarz na temat tego proroka, domniemany pešer, są to bardzo małe fragmenty, niestety, nie dostarcza on nam żadnego wyjaśnienia na temat tego aspektu.

10 E. Zw i, A Historical-Critical Study of the Book of Zephaniah, s. 23.

11 Tamże.

12 Tamże.

13 Na temat pochodzenia tej apokalipsy i jej tłumaczenie zob. G. S t e i nd o r ff, Die Apokalypse des Elias, eine unbekannte Apokalypse und Bruckstücke der Sophonias-Apokalypse: Koptische Texte, Übersetzung, Glossar, Leipzig 1899; O. S. W i n t e r m u t e, Apocalypse of Zephaniah, w: J. H. C h a r l e s w o r t h (red.), Old Testament Pseudepigrapha, t. 1, New York 1983, s. 497-515; zob. też A. K uś m i r e k, Apokalipsa Sofoniasza, w: M. P a r c h e m (red.), Pisma apokaliptyczne $i$ testamenty, AST t. 2, Kraków-Mogilany 2010, s. 133-168. 
W cyklu trzyletnim lektury Biblii w synagodze recytowano haftarah So 3,9-17.20 jako kontynuację seder z Rdz 11,1 i tak samo w święto Chanuka zawierano jako jedną z haftarot, które można było odczytać, to jest So 1,12n., natomiast w święto Szewuot czytano So 3,20.14

W czasach, kiedy rozwija się tradycja Targumu Jonatana, czyli w okresie trwającym od II w. przed Chr. do II w., Sofoniasz zostaje uznany za wielkiego proroka eschatologicznego i umieszczony w kategorii podobnej do Izajasza i Jeremiasza.

\section{Charakterystyczne zmiany ze względów teologicznych w Targumie Sofoniasza}

Celem aramejskich tłumaczy było dostarczenie przekładu ksiąg biblijnych, który byłby zrozumiały i jasny dla przeciętnego odbiorcy, jednocześnie targum miał odpowiadać koncepcjom i interpretacjom teologicznym ówczesnego judaizmu. Meturgemani stosowali w tym celu różnego rodzaju techniki translatorskie. Istotnym elementem staje się stosowanie charakterystycznych terminów, używanych do określania Boga.

\section{Obraz Boga}

W aramejskim przekładzie Księgi Sofoniasza widać wyraźnie tendencję do podkreślania transcendencji Boga z wykluczeniem ewentualnych antropomorfizmów. ${ }^{15}$

Tłumacz osiąga to często za pomocą stosowania słowa $q d m$, określanego teologicznym terminem „buforowym”. ${ }^{16} \mathrm{~W}$ ten sposób meturgeman wskazuje na godność Boga i tonuje Jego silne emocje,

14 J. R i b e r a F lo r i t, La versión aramaica del Profeta Sofonías, s. 127.

15 Np. Tg So 1,1.12; 3,5.15.17.

16 M. L. K l e i n, The Preposition QDM (before) a Pseudo-anti-Anthropomorphism in the Targums, JTS 36/1979, s. 502-507. Zdaniem M.L. Klein, qdm pełni rolę nie tyle antyantropomorficzną, ile raczej ma wyrażać szacunek i poważanie, por. Ezd 4,18; 7,14; Dn 2,10; 5,17. 
takich jak gniew. Pojawia się on w w. 1, gdzie JHWH nie mówi do człowieka bezpośrednio, ani nawet do proroka, lecz słowo w jakiś metafizyczny sposób zstępuje na niego „sprzed” Pana: „Słowo proroctwa od ${ }^{17} \mathrm{JJ},{ }^{18} \mathrm{które}$ było $z$ Sofoniaszem, synem Kusziego, synem Gedaliasza, synem Amariasza, synem Ezechiasza, za dni Jozjasza, syna Amona, króla pokolenia domu Judy" (Tg So 1,1).

Prorocze słowa, które są przed Nim, w pewien sposób przewyższają proroka w swego rodzaju metafizyczny sposób. Jednak gdy On mówi do narodów, że będą ukarane, słowo jest wyrażona jako „wyrok”: „Biada żyjącym na wybrzeżu, ludowi, który zastuguje na wyniszczenie, ${ }^{19}$ wyrok słowa Pańskiego jest przeciw wam, którzy mieszkacie w Kanaanie, kraju Filistynów, a Ja zniszczę was, aż nie zostanie ostatni z mieszkańców" (Tg So 2,5). Istotą Boga jest sprawiedliwość, która nigdy nie ustaje $(3,5)$, On bowiem jest prawdą $(2,3 b)$.

Według tłumacza człowiek nie może zbuntować się przeciw Bogu jako takiemu, lecz co najwyżej przeciw Jego słowu, tj. Memra $(3,11 \mathrm{a})$. Przez Memra Bóg objawia Torę swemu ludowi (por. 3,2). Ich cześć skierowana jest nie bezpośrednio do Boga jak w przypadku bóstw pogańskich, lecz do Jego obecności (3,9b). Bóg wymierza karę tylko grzesznym i niegodziwym: „Wszyscy grzesznicy ustali przed Panem, Bogiem, bo dzień, który przyjdzie od Pana,${ }^{20}$ jest blisko. Pan bowiem przygotował już rzezz, ${ }^{21}$ wezwat swych gości” (Tg So 1,7 zob. też 1,18a; $3,8 b)$.

Bóg jest ponad wszystkim i budzi grozę, bo zmiażdżył wszystkie bożki kraju (2,11a). Nie jest światłem, czyli słońcem, lecz jest niczym

17 Kursywą zaznaczane są dodatki do tekstu hebrajskiego, które występują w targumie.

18 Zapis imienia JHWH w targumie.

19 TM „ludowi Keretytów”. Midraszowa interpretacja Tg wychodzi od BH $k$-r-t - „ściąć”, „zniszczyć”; por. K. J. C a t h c a r t, R. P. G or d o n, The Targum of the Minor Prophets, s. 167.

20 Standardowy przekład aramejski określenia ,dzień Pański” (por. J1 1,15; M1 3,23).

${ }^{21}$ TM ,ofiarę” (por. TM i Tg Iz 34,6; Jr 46,10). 
światło poranka, które przybiera na sile (3,5b). Nie da się Go porównać z jakimikolwiek obiektami natury, które sam jest stworzył.

Bóg określa przeznaczenie człowieka (1,7; 2,5b.11a), a człowiek nie jest w stanie zmienić Jego postanowień: „W dzień gniewu Pańskiego nie uratuje ich ani srebro, ani ich złoto, a w ogniu Jego odpłaty ${ }^{22}$ zgina wszyscy grzesznicy ${ }^{23}$ ziemi, bo On sprawi kres ostateczny, a nawet zagładę, wszystkim mieszkańcom ziemi" (Tg So 1,18). Jest wojownikiem-wyzwolicielem, który kierowany miłością, ma upodobanie w przebaczaniu grzechów $(3,17 a)$. On dochowuje wierności danemu słowu i spełnia błogosławieństwa, które obiecał przodkom Izraela (3,7a).

Bóg nie wyśpiewuje sobie pieśni pochwalnych, lecz cieszy Go radość innych $(3,17 b)$, podobnie jak ma upodobanie w wynagradzaniu sprawiedliwych (3,7a).

Nie ma też ręki, którą by mógł wyciągnąć, mimo to grzesznikom wymierza cios swej potęgi $(1,4 ; 2,13)$. Tekst mówiący o tym, że człowiek mógłby znaleźć się „,za Bogiem”, sugeruje, że On ma plecy, tymczasem targum mówi o odwróceniu się od Boga: „... i tych, którzy odwrócili się od służby ${ }^{24}$ Panu i nie szukali bojaźni ${ }^{25}$ Pańskiej, i nie modlili się przed Nim" ${ }^{26 "}$ (Tg So 1,6). Odwrócenie się od Boga oznacza odejście od oddawania Mu czci: „Bóg nie powstaje ani nie podnosi się, lecz ukazuje się przez różnych «pośredników»: Dlatego wyczekujcie Mego Memra - mówi Pan - (i) dnia Mego ukazania się na wymierzanie saqdu, bo postanowiłem zgromadzić narody, zblizyć królestwa, aby wylać na nich Mój gniew, a nawet całą siłę Mego oburzenia - w ogniu Mej odplaty zgina ${ }^{27}$ wszyscy grzesznicy ziemi”" (Tg So 3,8). Użycie rdzenia $g$-l-' w stronie biernej lub zwrotnej to

22 TM ,zazdrości”.

23 Podobnie jak w Ha 2,20 targumista przez swoje uzupełnienie odrzuca koncepcję powszechnej zagłady (por. TM i Tg So 3,8).

24 Dodatek targumu, którego celem było wykluczenie jakiegoś bezpośredniego związku Boga z Jego czcicielami (por. 3,2).

25 Dodatek targumu (por. So 2,3).

26 TM „nie szukali Go”. Targumista nieustannie podkreśla ważność modlitwy.

27 TM ,cała ziemia zostanie pochłonięta”. 
często stosowana technika przez aramejskich tlumacz na oznaczenie objawienia się Boga. ${ }^{28}$

Według targumistów Bóg nie mógł mieć uczuć, takich jak ma człowiek. A zatem w Jego przypadku nie można mówić o zazdrości, lecz co najwyżej o ogniu odpłaty $(1,1 ; 3,8)$. Rzeczywistymi przekazicielami Jego woli i narzędziami odpłaty są Jego wysłannicy (1,12a) i prorocy $(1,1 ; 3,2 a)$. Dobro i zło urzeczywistniają się zgodnie z Jego słowem (1,12b). Prawo jest efektem Jego woli $(2,3 a)$. Strach i przerażenie budzi nie tyle On sam, ile Jego Szekinah (3,7a).

Nade wszystko, Bóg jest siłą, która stoi za wszystkimi wydarzeniami historycznymi, dlatego Targum Jonatana na każdym kroku używa stwierdzeń w 1. osobie liczby pojedynczej, np. „Ja zniszczę” $(1,3)$ czy „Ja spustoszyłem” $(3,6)$.

Zarówno w literaturze rabinackiej, jak i w Targumie Jonatana jest stosowany termin Szekinah, to jest Boża obecność, która choć ukryta, objawiła się człowiekowi. Ponieważ Bóg nie może fizycznie przebywać na jakimś miejscu, zamiast Niego w Jerozolimie przebywa właśnie Jego Obecność. Targum Jonatana podkreśla, że decyzja o przebywaniu na tamtym miejscu pochodzi od samego Boga: „Pan, Ten, który jest sprawiedliwy, obiecat, że będzie w niej przebywała Jego Szekinah" (3,5a. zob. też 15b.17a).

Ponadto w Targumie Sofoniasza pojawia się trzykrotnie wzmianka o tym, że Szekinah przebywa nie tylko w Jerozolimie i pośród Izraela, ale myśl o jej przebywaniu łączy kraj ze świątynią: „Powiedziałem: «Doprawdy, będziecie mieć bojaźń przede Mną, będziecie przyjmować pouczenia, a nie ustanie ich pobyt $w$ kraju domu Mej Szekinah. ${ }^{29}$ Ześlę na nich wszystkie błogosławieństwa, które im obiecałem. Wtedy spieszyło im się do deprawowania swych wszystkich dzieł»" $(3,7)$.

Łączenie kraju ze świątynią w taki sposób sugeruje uświęcenie pierwszego przez drugie. ${ }^{30}$ Targumista pośrednio wskazuje przez

28 Por. Tg Za 2,14.17; 14,3.

29 Por. również Tg So 2,9; 3,3.8.15.17.19.

30 Zob. Tg Iz 17,11; Za 9,1; zob. też: Tg Iz 2,3, gdzie byt skynt oznacza „dom Szekinah". 
to na możliwość wygnania $\mathrm{z}$ dala od Judei. Jeśli zatem Izraelici nie będą żyli w bojaźni Bożej, a Jego nauk nie wezmą sobie do serca, nie dane im będzie mieszkać w ziemi Izraela. Nie chodzi przy tym o perspektywę opuszczenia kraju przez Szekinah, lecz o koncepcję, że ziemia Izraela pozostanie domem Jego Obecności nawet wtedy, gdy Izrael pójdzie na wygnanie. ${ }^{31}$

\section{Relacja człowieka z Bogiem}

Człowiek nie może komunikować się z Bogiem bezpośrednio ani wprost zbliżać się do Niego. Boga nie można poszukiwać, bo nie ma ciała, więc jakakolwiek bliskość fizyczna nie wchodzi w grę. Można do Niego przystąpić tylko za pośrednictwem Tory lub nadprzyrodzonej sfery, która Go otacza i „kroczy” przed Nim: „Zgromadźcie się, przyjdźcie i zbliżcie się, ludu pokolenia, które nie chce powrócić do Prawa $^{32}$ " (Tg So 2,1 zob. też 1,6; 2,3a; 3,2b).

Tora zawiera Prawo Boże, ale uczy też o bojaźni Bożej, oddawaniu Mu czci, dobrych uczynkach itd. Na Boga nie można czekać lub Go wyglądać, co najwyżej można pokładać nadzieję w Jego słowie $(3,8 \mathrm{a})$, bo między obiema stronami zawsze istnieć będzie dystans. Ufności nie można pokładać w Bogu jako takim, lecz najwyżej w Jego słowie przekazywanym przez proroków $(3,2)$.

Bałwochwalstwo - to przestępstwo najbardziej godne potępienia i korzeń wszelkiego zła. To ono doprowadziło do zniszczenia świątyni i deportacji. Znaczy to samo przez się, że „grzesznicy” to bałwochwalcy. Bałwochwalstwo przejawia się w synkretyzmie religijnym, apostazji i agnostycyzmie, oddawaniu czci zarówno JHWH, jak i bogom obcym. Przysięgali w imię JHWH, a potem powtarzali swe śluby w imię ich bożków „A przeciw ludowi Judy i przeciw wszystkim mieszkańcom Jerozolimy podniosę Mój potężny bicz ${ }^{33}$

31 A. H o, The Targum of Zephaniah, s. 414.

32 Strona czynna czasownika wymagała teraz dopełnienia, a posłuszeństwo Prawu zawsze było tematem na czasie i na miejscu.

33 TM ,wyciągnę Mą rękę” (por. So 2,13). 
i wytracę z tego miejsca pozostałości Baala, imiona ich czcicieli ${ }^{34}$ i ich kapłanów pogańskich, ${ }^{35}$ i tych, którzy na dachach ${ }^{36} \mathrm{kłaniają} \mathrm{się}$ zastępom niebieskim, i tych, którzy kłaniają się i przysięgają na imię Pana, (a potem) znów się odwracają i przysięgają na imię swych bożków" (Tg So 1,4b-5). Judejczycy oddawali cześć Baalowi i pozwalali kapłanom odprawiać dla nich nabożeństwa. Czcili zastępy niebieskie, chcieli, aby oddawać cześć bałwanom i naśladować drogi Filistynów (1,4-5.8-9). W tym dążeniu byli tak zapamiętali, że naśladowali nawet tych, którzy mieszkali w kraju Kanaan przed podbojem $(1,11 b)$. Bałwochwalcy muszą zostać wykorzenieni, dlatego należy ich dokładnie poszukać, bo kalają świętość miasta i kraju. Bogactwo jest źródłem herezji $(1,12)$, ale także bałwochwalstwa i działalności przestępczej: „Rozpaczajcie, mieszkańcy doliny Cedronu, ${ }^{37}$ bo wyginęli wszyscy ludzie, których dzieła sa jak wytwory ludzi kraju Kanaan, ${ }^{38}$ wszyscy majacy wiele posiadłości ${ }^{39}$ zostali zniszczeni”" $(1,11)$.

34 TM „kapłanów” w odniesieniu jednak do pogan. Według Smolara i Aberbacha (c i ż, Studies in Targum Jonathan to the Prophets, s. 38) targumista wprowadził tu „czcicieli”, bo uważał, że TM hkhnym musi przetłumaczyć jako „kapłani pogańscy”.

35 W targumie jest kwmryhwn - ,ich kapłanów (pogańskich)”, podobnie, tam gdzie BH khn oznacza kapłana pogańskiego lub w jakiś inny sposób nieprawomocnego (np. 1Krl 12,31n.).

36 Możliwe jest też: „przed pogańskimi ołtarzami” (por. Am 3,14), ale za proponowanym tłumaczeniem przemawia przyimek ' $l$ - zwykle „,na”, tak jak w większości rękopisów targumu; K. J. C a t h c a r t, R. P. G o r d o n, The Targum of the Minor Prophets, s. 165 przyp. 8.

37 TM „Moździerz” lub „Wgłębienie”. Mogło tu chodzić albo o dolinę Cedronu, co wybrał targumista, albo o Tyropeon. Ponieważ jednak w pozostałej części tego wiersza mowa jest o terenie handlowym, większość opowiada się za lokalizacją w obrębie miasta, tj. w dolinie Tyropeon.

$38 \mathrm{TM} k l$ ' $m$ kn'n, gdzie $k n$ 'n prawie na pewno oznacza nie „Kananejczycy”, lecz „kupcy”, jak o tym świadczy zaraz następny fragment (por. przekład wzmianek o Sodomie i Gomorze w Tg Iz 1,10 i o Sodomie w Tg Pal Pwt 32,32).

39 Targumista zastosował tu wyrażenie standardowe (por. Iz 14,8.9; 53,9; Ez 39,18; Am 4,1; Za 11,2), które tak naprawdę nie czyni zadość zdecydowanie komercyjnej wymowie TM. Być może wersja hebrajska została odczytana w sensie: „obładowani srebrem". 
Grzech można odkupić przez okazywanie bojaźni Bożej (1,6b; 2,3), ona bowiem prowadzi do skruchy i powrotu do życia Torą $(2,1 b ; 3,13)$. Zbliżenie się do Tory, czyli do Boga, może odwrócić Boże wyroki i zażegnać Jego zapalczywy gniew (2,1-2).

\section{Znaczenie modlitwy}

Targum Jonatana mocno podkreśla wartość modlitwy jako odzwierciedlenia religijności i wiary człowieka. ${ }^{40}$ „Kłanianie się” interpretowane jest jako „modlenie się przed Bogiem” (2,11b). Podobnie „przywoływanie Jego imienia”. Targumista podkreśla, że modlitwę należy odmawiać w jednym języku: „Wtedy znów ześlę na narody jeden [wspólny] wybrany język, żeby wszyscy mogli modlić się w imię Pana, żeby mogli zgodnie służyć przed Nim" (Tg So 3,9).

Parafraza targumu może kryć w sobie sugestię dotyczącą powrotu do sytuacji sprzed wieży Babel, kiedy „,cała ziemia miała jeden język i kilka słów" (Rdz 11,1). Chodzi o język hebrajski, bo tym językiem mówili wszyscy ludzie na ziemi, zanim zbudowali wieżę Babel. Posługiwanie się różnymi językami było początkiem spirali upadku, a jednocześnie dało początek bałwochwalstwu (3,9b). Bóg wzywa ludzi, by chwalili Go, gdy przyjdzie wybawienie: „Daj chwałe, zgromadzenie ${ }^{41}$ Syjonu, krzycz z radości, Izraelu, raduj się i wesel z całego serca, zgromadzenie Jerozolimy" (Tg So 3,14). Bóg obiecuje uczynić ich samych obiektem chwały $(3,19 b)$.

40 Na temat znaczenia modlitwy w targumach: L. S m o l a r, M. A b e r b a c h, Studies in Targum Jonathan to the Prophets, s. 164-169, zob. też M. B a r a $\mathrm{n}$ i a k, Słowo „,modlitwa” [şlw/şly] w aramejskich targumach do Biblii Hebrajskiejz perspektywy tekstów palestyńskich (II w. p.n.e. - I w. n.e. oraz VIII w. n.e.), w: A. R ó ż yło (red.), Modlitwa w językach i tekstach artystycznych, Sandomierz 2007, s. 35-53; A. K u ś m i r e k, ,Zbawienie mej duszy nastapi dzięki modlitwie do Pana" (TgJon 2,10b). Rola modlitwy w targumach, w: W. C h r o s t o w s k i (red.), „Jak śmierć potężna jest miłość” (Pnp 8,6). Księga pamiątkowa ku czci Księdza Profesora Juliana Warzechy SAC (1944-2009), Apostolicum, Ząbki 2009, s. 250-258.

${ }_{41}$ TM ,córko”, które w targumie zastępuje knst', ,zgromadzenie”; czasem można tłumaczyć jako ,synagoga”. 
Modlitwa ukazana zostaje jako oddawanie chwały, zwłaszcza po zburzeniu świątyni, gdy właśnie modlitwa zastąpiła składanie ofiar i inne czynności kultyczne. W oczach rabinów zyskała ona najwyższą wartość, czemu dali wyraz w wielu głębokich rozważaniach i traktatach. ${ }^{42}$ Modlitwa przewidziana jest na każdą sytuację i okoliczność życia.

Nagroda dla sprawiedliwych i kara na grzeszników

Wszelkie działania człowieka wartościowane są w kategoriach dobra i zła: tak też ocenia je Bóg, za pierwsze nagradzając, a za drugie karząc. ${ }^{43}$ Ponieważ On jest najwyższym Sędzią, a jedną z istotnych cech Jego natury jest sprawiedliwość, człowiek winien dać się Bogu prowadzić. Skoro On jest sprawiedliwy șaddî $q(3,5 \mathrm{a})$, to sprawiedliwych można nazywać șaddîqîm. Za swoją pobożność i dobre uczynki sprawiedliwi zostają wynagrodzeni mocą duchową, która daje im możliwość zmiany Bożych postanowień, oraz darem bliskości z Nim: „Zgromadźcie się, przyjdźcie i zbliżcie się, ludu pokolenia, które nie chce powrócić do Prawa, zanim sąd wyda przeciw wam postanowienie i staniecie się niczym plewy na klepisku, które wiatr rozmiata, i jak cień, który przemija przed dniem; zanim spadnie na was siła ${ }^{44}$ gniewu Pańskiego" (Tg So 2,1-2). Ich modlitwy zostają wysłuchane i spełnione, a ich zasługi zbawiają zarówno ich, jak i ich potomków (2,7b). Łakną i pragną Tory, prawdy i bojaźni Bożej (2,1-3), odrzucają kłamstwo i oszustwo, bo tym Bóg się brzydzi. Są skromni i pokorni, znoszą poniżenie, ufność pokładają w Bogu $(3,12)$, z ich ust nie padają złe słowa, ich nagrodą jest opieka Boża i bezpieczne życie: „Reszta Izraela nie będzie działać podstępnie ani mówić kłamstwa. W ich

42 A. Ho, The Targum of Zephaniah, 413.

43 L. S m o l a r, M. A b e r b a c h, Studies in Targum Jonathan to the Prophets, s. $169-187$.

44 TM Hron - ,płonący gniew” (por. Tg Iz 13,13; So 3,8). 
ustach nie znajdzie się podstępnego języka, bo będa się utrzymywać i osiedla się, ${ }^{45}$ a nie będzie takiego, którego by się bali” (Tg So 3,13).

Świat nie może zostać całkiem zniszczony, ponieważ Bóg obiecał sprawiedliwym nagrodę, gdy wszyscy grzesznicy zostaną już wytępieni $(1,18)$. Natomiast losem wszystkich grzeszników będzie zniszczenie ich ,sprzed” Boga (1,7a). Popełnili zbyt wiele zła, by można było je wytrzymać (1,3a).

Według Targumu Jonatana bogactwo sprzyja grzesznemu zachowaniu, zuchwałości, samozadowoleniu, agnostycyzmowi i upodabnianiu się do otoczenia. ${ }^{46} \mathrm{Ci}$, którzy występują przeciw Bogu, występują też przeciw człowiekowi, i na odwrót: oddają cześć obcym bogom $(1,5 b)$ i kwestionują potęgę Boga $(1,12 b)$. Swą pozycję ekonomiczną lub polityczną wykorzystują do mnożenia oszustw i podstępów (1,9b; 3,1-4). Po zdobyciu bogactwa zamiast angażować się w czynienie dobra i krzewienie wiary, trzymają się na uboczu i do wszystkiego odnoszą się sceptycznie $(1,11 b ; 12,2)$. Za kroczenie ścieżkami grzechu oni sami i ich bogactwa przepadną z kretesem, a nie będzie nikogo, kto by ich uratował (1,7a.13a.18). Ich los będzie jak złożenie ofiary, ponieważ skalali to, co święte $(3,1)$. Nawet ich zwłoki nie zaznają spokoju ani odpoczynku $(1,17 b)$.

Bez względu na to, czy chodzi o Izraela, czy o narody obce, Bóg ukarze grzeszników ogniem swej odpłaty $(1,18 \mathrm{a} ; 3,8 \mathrm{~b})$. Grzeszna działalność może być przerywana okresami świątecznymi, przystąpieniem do wojny z Żydami lub przez ich zniesławienie $(2,8.10$; $3,18)$. Grzechem jest bycie zarozumiałym, zuchwałym $(1,15 ; 3,11)$ i niewdzięcznym $(3,7)$.

45 Kojarzącą się ze zwierzętami terminologię TM („leżeć”, „wypasać się”) targumista sparafrazował za pomocą czasowników, które bardziej pasują do zachowania ludzi.

46 A. H o, The Targum of Zephaniah, s. 414. 


\section{Dzień JHWH}

Dzień JHWH biblijnej Księdze Sofoniasza w targumie zostaje interpretowany w sposób homiletyczny. ${ }^{47}$ Prawdopodobnie to zburzenie obu świątyń i długie lata walki z hellenistycznym i rzymskim okupantem sprawiły, że - według targumu - prorok nie wypowiadał się tylko o jednym dniu odpłaty. Rabini wypracowali zawiłą ideologię świata przyszłego. Targum mówi o tym dniu jako o pewnym okresie: ${ }^{10} \mathrm{~W}$ owym czasie - mówi Pan - słychać będzie odgłos płaczu od Bramy Rybnej i zawodzenia z Ofelu ${ }^{48}$ i głośny trzask ze wzgórza (...). ${ }^{12} \mathrm{~W}$ owym czasie dojdzie do tego, że Ja wyznaczę szukajacych, a oni przeszukaja mieszkańców Jerozolimy jak ludzie szukaja z pochodnią ${ }^{49}$ i nawiedzę z wizytą ludzi, którzy $w$ spokoju wylegują się na swych włościach ${ }^{50}$ i którzy mówią sobie w sercu: «Pan nie jest usposobiony $^{51}$ do czynienia dobra ani nawet/choćby do czynienia zła»" (Tg So 1,10.12).

Kiedy odwołuje się do tekstu, w którym występuje termin ,ów dzień, targum dodaje: „który przyjdzie od JJJ” (1,7.8.14). W „owym czasie” Bóg dokona sądu nad bałwochwalcami z Jerozolimy i jej sąsiedztwa. Termin „dzień” zdaje się odnosić do wielu różnych wydarzeń. Będzie to dzień zabijania i mordowania grzeszników, którzy oddawali się bałwochwalstwu i są zepsuci. Będzie to dzień, w którym pałace zostaną splądrowane, a możnowładcy stracą życie. Będzie to dzień wielkiego zgiełku (1,14b.15b), w którym Bóg podejmie decyzję o ostatecznej zagładzie (1,18b). Będzie to dzień, kiedy Bóg ukaże się

47 Tamże, s. 415.

48 TM ,nowej dzielnicy”.

49 TM ,z pochodniami przeszukam Jerozolimę”. Targumista wychodził z założenia, że czegoś takiego nie mógłby zrobić sam Bóg, lecz musieli jacyś Jego wysłannicy (por. Am 9,3; Jr 49,10, gdzie TM hspty zostaje potraktowane metatetycznie jako hpsty); K. J. C a t h c a r t, R. P. G o r d o n, The Targum of the Minor Prophets, s. 167 przyp. 28.

50 TM „którzy tężeją na swych śmieciach”. Targum znów atakauje bogatych (por. TM i Tg Jr 48,11).

${ }^{51}$ Dosł. „nie jest przyjemnością przed Panem”. 
narodom świata jako najwyższy Sędzia, by sprowadzić na ziemię królestwo niebieskie i zainaugurować epokę mesjańską $(3,8)$.

Błogosławieństwo ze względu na zasługi przodków

Miłość Boga do Izraela jest niezachwiana przez wzgląd na zasługi sprawiedliwych. Na świat przybędą Boży posłańcy, by szukać grzeszników wypoczywających na swych włościach $(1,12)$ i uratować sprawiedliwych.

Według targumu do ocalenia prowadzi droga prawdy, bojaźni Bożej i życia Torą (2,1-3). Zasługi przodków „działać” będą przed Bogiem niczym błogosławieństwo, dzięki czemu Izraelici powrócą z ziem swego wygnania: „Tam będzie $d z i a t^{52}$ dla reszty z domu Judy. Tam będą się z nich utrzymywać, wieczorem wypoczywać będą w domach Aszkelonu, gdyż zapis o nich ukaże się dla ich dobra ${ }^{53}$ przed Panem, ich Bogiem, a On sprowadzi ich wygnańców" (Tg So 2,7b). W części drugiej tego wersetu targumista kładzie tu nacisk na doktrynę o zasługach człowieka.

Bóg słyszy, jak narody wynoszą się nad Izraela, a ich chełpienie się bierze do siebie osobiście $(2,8.10)$. Dlatego postanowił wyzwolić swój lud (2,11a) i z miłosierdziem sprowadzi go z krajów, do których zostali uprowadzeni w niewolę. Narody zamieszkujące tereny aż po rzeki Indii po swym nawróceniu sprowadzą „Mój lud” jako dar dla Boga: „Zza rzek Indii ${ }^{54}$ wygnańcy z Mego ludu, którzy byli $w$ niewoli, ${ }^{55}$ powróca $w$ miłosierdziu i samych siebie przyniosą $\mathrm{w}$ darze" (Tg So 3,10). Wedle tej koncepcji Bóg nie odrzuci rozproszonych pokoleń izraelskich z królestwa północnego: one też powrócą do ojczyzny i wezmą w posiadanie tereny na wschód od Jordanu $(2,9)$.

52 TM $h b l$-,wybrzeże (morskie)” targumista przypisał znaczenie „dział” i w ten sposób wprowadził rozróżnienie między terenem nadmorskim a terytorium, które ma wziąć w posiadanie reszta Judy.

53 TM „będą ich doglądać” (por. TM i Tg Jr 29,10).

54 TM „(krainy) Kusz” (por. Iz 11,11; 18,1; Jr 13,23). W b.Meg. 11a znajduje się omówienie wyrażenia „od Indii do Kusz” (Est 1,1; 8,9).

55 TM pwsy - „moi rozproszeni” (por. LXX, Wlg, Symm). 
Błogosławieństwa, które Bóg obiecał Izraelowi, w dalszym ciągu będą realizowane (3,7a). Zgładzi wszystkich odwiecznych wrogów i nieprzyjaciół (3,15a.18a), którzy podnosili broń przeciw Izraelowi (3,18b). Odpuści grzechy $(3,17 b)$ swego zgromadzenia $(3,14)$, wyzwoli go (3,17a), podobnie jak uprowadzonych i rozproszonych (3,19b). Radować się będzie z wyzwolenia Jego ludu $(3,17 b)$. Podobnie radować się będzie Syjon i zanosić do Niego głośne modlitwy pochwalne $(3,14 a)$.

\section{Inne zmiany i modyfikacje w Targumie Sofoniasza}

Oprócz przytoczonych tu zmian ze względów teologicznych w Targumie Sofoniasza występują często jeszcze innego rodzaju objaśnienia, modyfikacje wprowadzenie dodatkowego materiału, np. targumista dodaje jedno lub wiele słów, aby uzupełnić sens tekstu oryginalnego o charakter czy wyjaśniający, czy też interpretacyjny. Do uzupełnień wyjaśniających należą następujące przykłady, np. dodatnie słowa „prorocze” do „słowa” (1,1), „złe” do „,czynów” $(3,11)$, „fałszywi’ do „proroków” $(3,4)$. Ponadto dodawane są wyrażenia takie, jak ,z pokolenia domu” $(1,1)$,lud” $(1,4)$ a także inne terminy, np.: „Szukajcie bojaźni Pańskiej, wszyscy pokorni tej ziemi, którzy przestrzegaliście sądów Jego upodobania, ${ }^{56}$ szukajcie prawdy, ${ }^{57}$ szukajcie pokory - może doznacie ochrony ${ }^{58} \mathrm{w}$ dniu gniewu Pańskiego".

Nierzadko w targumie są zastosowane jednocześnie zmiany i dopełnienia, które, chociaż w niektórych przypadkach mają wartość wyjaśniającą (np. „mający wiele posiadłości” ${ }^{59}$ zamiast „ci, którzy ważą srebro" -1,11). Tego rodzaju zmiany wynikają z typowo targumicznej

56 TM ,Jego polecenia”.

57 TM SD - „sprawiedliwości”.

58 TM „ukryjecie się”. Przekład targumu mówi o „ochronie” wprowadza ideę dobrych uczynków, które w dzień sądu świadczą na korzyść człowieka.

59 Targumista zastosował tu wyrażenie standardowe (por. Iz 14,8.9; 53,9; Ez 39,18; Am 4,1; Za 11,2), które tak naprawdę nie czyni zadość zdecydowanie komercyjnej wymowie TM. 
egzegezy. ${ }^{60} \mathrm{~W}$ ten sposób np. hebrajskie wyrażenie „ci, którzy ubierają się w cudzoziemskie sztaty" 61 zostaje zinterpretowane jako „ci, którzy przepychaja się, by cześć oddawać bałwanom. Targumista najwyraźniej miał na myśli $2 \mathrm{Krl}$ 10,20-22 i tłoczących się czcicieli Baala, poubieranych w szaty kultyczne. Podobnie hebrajskie: „ukarzę wszystkich, którzy pewnie przekraczają próg pałacu" zostaje przetłumaczone jako „którzy postępuja zgodnie z prawami Filistynów”. ${ }^{62}$ Targumista dopatrzył się tutaj aluzji do $1 \mathrm{Sm}$ 5,5. W innym miejscu targumista objaśnia hebrajskie wezwanie „milczcie przed obliczem Wszechmogącego”, parafrazując jako „wszyscy grzesznicy ustali [dotarli do swego końca] przed Panem" $(1,7)$.

Targum wprowadza zmiany w zakresie gramatyki, składni i liczby, aby tekst prozatorski był dla czytelnika bardziej zrozumiały. ${ }^{63} \mathrm{Na}$ przykład mogące budzić wątpliwości konstrukcje: 'āsōp 'āsēp zostaje oddane w 1. osobie jako - „na pewno zniszczę” $(1,2)$.

Druga osoba liczby pojedynczej zostaje zmieniona na liczbę mnogą w 3,7, gdzie wszystkie słowa występują w liczbie mnogiej zamiast częściowo w pojedynczej, a częściowo mnogiej, jak w wierszu poprzednim i następnym.

Tam, gdzie brakuje czasownika w imperfectum, dodany zostaje czasownik „będziecie” $(2,12)$. Wszystkie części architektoniczne miasta Niniwy opisane zostają w dopełniaczu, by co do formy odpowiadały $b^{e} k a p t \bar{o} e^{y} h a(2,14)$. „Odgłos dnia JHWH” powiązany zostaje z „przenikliwe wołanie” za pomocą wyjaśniającego „w którym”. W ten sposób „odgłos” i „krzyki” oddzielone zostaje od enigmatycznego „tam wojownik” i wprowadza obraz owego dnia jako czasu „ucisku i płaczu”.

60 J. R i b e r a F lo r i t, La versión aramaica del Profeta Sofonías, s. 129.

${ }_{61}$ TM ,obce [nkry] szaty” sugerowałoby BH $n-k-r$, które często występuje w związku z bałwochwalstwem (por. Rdz 35,2.4; Pwt 31,16; 32,12).

62 Por. j. AZ 3,2; Hieronim; Raszi; zob. też TM i Tg Iz 2,6.

${ }_{63}$ Zob. m.in. J. R i b e r a F 1 o r i t, La versión aramaica del Profeta Sofonías, s. 130nn.; A. H o, Targum Zephaniah, s. 416-418. 
Zmiany wprowadzane w tekście aramejskim przez targumistów mają na celu przekazanie zrozumiałego tekstu. Tak jest np. w 3,5b, gdzie tekst jest skażony gramatycznie, a dzięki przekształceniu w analogię staje się czytelniejszy. Przy okazji daje okazję wyrażenia prawdy teologicznej, jakimi drogami Bóg zaprowadza sprawiedliwość, oraz skrytykowania czasów współczesnych targumie.

Zmiana liczby pojedynczej na mnogą następuje zwłaszcza wtedy, gdy w tekście mowa jest o bałwochwalstwie czy też innym nieetycznym postępowaniu. Na przykład mieszkańcy Judei kłaniali się zastępom niebieskim (1,5), dopuszczali się nieprawości i kłamstw (1,9; $3,13)$, a Moab okrył się niesławą $(2,8)$. Czasem takie zmiany wprowadzone zostają w celu ujednolicenia osoby, liczby i sufiksów.

Podobnie jest $\mathrm{z}$ tekstami o karze, które również przekształcone zostają w liczbę mnogą. Niegodziwcy zostaną zabici $(1,14)$, a ich zwłoki napełnią ziemię niczym odpadki $(1,17)$. Kraj nieprzyjaciół zamieni się w miejsca wydobywania soli i doły solne $(2,9)$. Wrogowie Izraela zostaną zgładzeni $(3,15)$.

W ten sam sposób zmiany i uzupełnienia są użyte, by wyjaśnić metafory i wyrażenia symboliczne z tekstu hebrajskiego, dodając często słowo porównawcze ,jak”, ,podobne do” (2,2; 3.3.10.19). Typowe dla targumu jest rozumienie „paść bydło” w znaczeniu ,podtrzymywać” $(2,7 ; 3,10)$ i „córki Syjonu” jako „zgromadzenia Syjonu” $(3,14)$. Tak samo nazwy własne są czasami uaktualniane: Makteš przekształca się w „strumień Cedron” $(1,11)$, nowa dzielnica Jerozolimy (Mišneh) w cOfla' $(1,10)$, a Etiopia w Indie $(3,10) .{ }^{64}$

Przekład często ma charakter wyjaśniający, zwłaszcza w miejscach trudnych. Na przykład „potęga” symbolizuje „domy”, a „domy” „pałace” (1,13). „Narożniki” to „wysokie wzgórza” $(1,16)$, a kaptōrîm oznacza płaskorzeźby i inskrypcje na bramach $(2,14)$. „Mężczyzna” stanowi odpowiednik „ludzi”, a ściśle rzecz biorąc „,dzieci” ludzkich $(1,17)$, natomiast „,ciało/mięso” to „zwłoki” $(1,17)$. Słowo ketōrîm

${ }^{64}$ Tak zarysowana mapa wskazuje na północ (Brama Rybna), południe (Ofel), zachód (Wzgórze) i wschód (Dolina Cedronu); J. R i b e r a F 1 o r i t, La versión aramaica del Profeta Sofonías, s. 134n. 
należy odczytywać jako stronę bierną czasownika $k^{e}$ rutîm - „zasługiwać na odcięcie” $(2,5)$. „Kanaan” oznacza mieszkańców kraju”. Trudne wyrażenie $n^{e}$ wōt $k^{e}$ rōt roi ${ }^{i} \hat{\imath} m$ zostaje wyjaśnione w nawiązaniu do środowiska pasterskiego $(2,6)$. Tekst 2,7 trzeba interpretować metaforycznie, ponieważ ludzie nie wypasają się jak zwierzęta, lecz „zdobywają środki na utrzymanie” i ,spędzają noc”. Niezwykły zwrot haytô- $\bar{g} \hat{o y}$ zostaje przetłumaczony za pomocą zwyczajnego „zwierzę polne” $(2,14)$. Czasem - w celu jasności przekładu - w tekście następuje apozycja, np. „,ich miejscem zamieszkania” jest „kraj”, „miejsce przebywania” Szekinah.

Podobnie jak sami prorocy Targum Sofoniasza korzysta ze starszych tradycji literackich, aby wyjaśnić tę czy inną kwestię. Na szczególną uwagę zasługuje bardzo trudny fragment 3,1, który targum zamiast kontekstu wyzwolenia przez odwołanie się do Kpł 1,16 prezentuje jako surowe ostrzeżenie. W 1,2 pobrzmiewa echo opowiadania o pokoleniu potopu. Tekst 2,2 zdaje się nawiązywać do Oz 13,3. W 3,9 można dopatrzeć się aluzji do opowiadania o wieży Babel. O ile targum odzwierciedla zwykle poglądy rabinów, o tyle w tym przypadku można mówić o pewnej dwuznaczności czy niejasności. Targum Sofoniasza powtarza słowa i wyrażenia występujące w księgach wcześniejszych, by zapewnić jednolitość interpretacji i przekładu.

$$
* * *
$$

Według kryterium targumicznego jest logiczne, że zmiany i dopełnienia interpretacyjne mnożą się, kiedy tekst masorecki sam w sobie jest trudny do zrozumienia. Podobnie jak w przypadku objaśnień metafor i wyrażeń symbolicznych.

Wiele terminów i zwrotów charakterystycznych dla targumu odzwierciedlają wrażliwość w związku z transcendencją Boga. Przede wszystkim chodzi o użycie boskiego Memra jako narzędzia zbawienia i napomnienia prorockiej; podobnie użycie Szekinah jako znaku obecności zbawiennej JHWH. Powszechne jest również użycie przyimka „przed” przy zwracaniu się do Boga (1,16; 2,7; 3,7.9). Według 
tego sposobu myślenia nie szuka się, nie podąża się za ani nie zbliża się do JHWH, nie szuka bojaźni JHWH lub nie odwraca się od Jego kultu. JHWH „,nie wyciąga swojej dłoni”, tylko „zadaje cios swoją mocą”; ,zazdrość JHWH” przekształca się w „zemstę”, a koncepcja „objawienia” zastępuje wyrażenia ludzkie przypisywane boskości.

Uwrażliwienie na sprawy moralne targum ujawnia w wielu miejscach przez dodawanie słów w celu sprecyzowania wartości moralnej danych postaci lub czynów. Kwestie proroctwa - prawdziwego czy fałszywego - i nauczania stają się znaczące $(3,2.4)$, ale są też pewne interesujące nowe elementy. Wielkie oskarżenie, które stawia się Izraelowi to fakt, że nie chce „nawrócić się na Prawo”.

Targumista wykorzystuje tekst Sofoniasza, by podkreślić swoje upodobanie do ery eschatologicznej, jako że oryginał hebrajski poświęca jej wiele uwagi, szczególnie dotyczy to dnia sądu. Przede wszystkim, akcentuje ostateczną zagładę bezbożnych i bałwochwalców. W ten sam sposób podkreśla definitywny powrót wygnanych i zbawienną obecność JHWH pośród swego ludu, wyrażona przez Szekinah. Dzień zemsty, „pochodzącej od JHWH”, niebawem przybędzie, jako dzień sprawiedliwości dla nikczemnych, ale radości dla „zgromadzenia Syjonu”, które pozostanie i będzie wyzwolone od wszystkich swoich ciemiężycieli. W taki właśnie sposób targum wpisuje się w przekaz nadziei, która stanowi klucz interpretacyjny ksiąg prorockich dla odbiorców. Interpretacja ta jest zgodna z przesłaniem całego Targumu Jonatana, zawierającego rabiniczne koncepcje teologiczne.

Anna KUŚMIREK

Słowa kluczowe: Księga Sofoniasza, Targum Jonatana, przekład aramejski Keywords: Book of Zephaniah, Targum Jonathan, Aramaic translation 


\section{The Aramaic Version of the Book of Zephaniah}

\section{Summary}

The chief aim of this article is to show the key features of the Aramaic version of the Book of Zephaniah, that is a part of the Targum Jonathan. The first section of the research discusses the most important aspects of the theological concepts of Targum Jonathan based on examples from Targum Zephaniah. The second part of the article also presents some features of targumic renderings. 